\title{
The challenge of young Romanian designers: creativity in business
}

DOI: 10.35530/IT.071.03.1818

DENISA BOGDANA ABRUDAN

MARGARETA STELA FLORESCU

MĂDĂLINA DUMITRIȚA MATICIUC

DANA CODRUȚA DĂIANU

MARIAN NĂSTASE

\section{ABSTRACT - REZUMAT}

The challenge of young Romanian designers: creativity in business

The present paper focuses on the subject of creativity in business starting from a set of interviews with young designers (fashion designers mostly, but not exclusively). In order to provide an updated overview of the "ecosystem" of creativity, we intend to add to the field literature, thus offering a more comprehensive understanding of creativity by focusing on the role of designers in facilitating or inhibiting creativity in business in the fashion industry. The work was limited contextually to the fashion sector in the western region of Romania, with the data being collected through semi-structured interviews with entrepreneur fashion designers (producers of clothing, footwear and accessories). The analysis aims to identify and highlight the attributes of entrepreneur designers in the creative industry, as well as the ways in which they are inclined to develop their creativity in order to combine various materials or textures into something original. The results of our research are in fact empirical evidence regarding the strategic role of entrepreneur designers when it comes to creativity in business, a role that can allow them to achieve durable competitive advantage for their own businesses by developing both the analytical skills necessary for interpreting economic data to validate an idea, and the intuitive skills regarding the economic climate. Although the specific context may be considered a limitation of the study, it may become a real advantage for potential future research that will extend the boundaries of the present one.

Keywords: entrepreneurship, creative industry, fashion design, passion, imagination, competitive advantage

\section{Provocarea tinerilor designeri români: creativitatea în afaceri}

Lucrarea de față se concentrează pe tema creativității în afaceri pornind de la un set de interviuri cu tineri designeri (mai ales designeri de modă, dar nu exclusiv). Pentru a oferi o imagine de ansamblu actualizată a „ecosistemului” creativității, a fost prezentată literatura de specialitate din domeniu, oferind astfel o înțelegere mai cuprinzătoare a creativității, prin concentrarea pe rolul designerilor în facilitarea sau inhibarea creativității în afaceri în industria modei. Cercetarea s-a limitat contextual la sectorul modei din regiunea de vest a României, datele fiind colectate prin interviuri semi-structurate cu designeri de modă antreprenori (producători de îmbrăcăminte, încălțăminte și accesorii). Analiza își propune să identifice și să evidențieze atributele designerilor antreprenori din industria creativă, precum și modalitățile în care sunt înclinați să iși dezvolte creativitatea, pentru a combina diverse materiale sau texturi cu abordări originale. Rezultatele cercetării sunt de fapt dovezi empirice cu privire la rolul strategic al designerilor antreprenori, atunci când discutăm despre creativitatea în afaceri, rol care le poate permite să obțină un avantaj competitiv durabil pentru propriile afaceri, prin dezvoltarea atât a abilităților analitice necesare interpretării informațiilor economice pentru validarea unei idei, cât și a abilităților intuitive cu privire la climatul economic. Deși contextul specific poate fi considerat o limitare a studiului, acesta poate deveni un avantaj real pentru cercetările viitoare, care vor depăși limitele celei prezente și pot valida și în alt context rezultatele obtinute.

Cuvinte-cheie: antreprenoriat, industrie creativă, design vestimentar, pasiune, imaginație, avantaj competitiv

\section{INTRODUCTION}

As companies have become increasingly oriented towards gaining and maintaining competitive advantage by stimulating the creativity of their employees [1] we deem it important to understand how creativity in the entrepreneur designers' workplace can be facilitated or inhibited, by analysing their attributes and the individual manner in which the creative process unfolds.

In the last decades multiple studies have been carried out that have provided information of great importance regarding creativity. However, there is still a significant lack of qualitative research on this topic, the literature showing a predominance for quantitative research. For example, the works of Guilford [2] involved simply counting ideas, with no regard for the qualitative element, i.e. that arbitrariness of ideas. Torrance [3] analysed 388 correlations between intelligence and creativity. These pioneering tests were criticized [4] on the grounds that they were aimed at measuring creative intelligence and not creativity itself, but also because they used preponderantly quantitative analyses. This aspect continued even after the 2000s, when Vincent and his colleagues [5] analysed the correlation between intelligence and 
expertise. Thus, in order to rebalance the literature, we considered it relevant to carry out a qualitative research on the topic of creativity and to channel it into the business environment.

The economic environment has caused companies to focus on creativity. Thus, in order to survive in an environment that is changing at an unpredictable speed [6], organizations must stimulate the creativity of their employees, as their ideas are essential if they are to remain innovative and competitive [7]. Florinda [8] argued that people, through their creative potential, are key elements in adding economic value to their sector of activity.

Moreover, although there are several studies on creativity in business, they focus mainly on critical actors such as managers and employees from large fashion houses or large companies. In this regard, our paper innovates by presenting interviews with designers in charge of their own business, in order to shed light on how they perceive creativity in business. We intended to focus on a qualitative research on creativity in business, on the analysis of the creative process in the fashion industry by conducting interviews with Romanian entrepreneur designers.

\section{LITERATURE REVIEW}

The notion of creativity has a long history, its study appearing to have increased at the beginning of the $20^{\text {th }}$ century, especially in the field of psychology [9-10]. Nowadays, the concept of creativity is associated with the ability to bind unique connections, the emergence of new products [11] or the development of new and distinctive solutions for the existing problems [12].

As organizations face increasingly complex challenges, their ability to adapt and properly manage innovation projects is crucial in order to achieve longterm success and competitiveness [13].

There is ample evidence in favour of regarding the concept of creativity as having relevance in facilitating entrepreneurial success [14], an attribute that ensure the entrepreneurial process and can decisively help in discovering new business opportunities [15]. Entrepreneurship in the creative industries (creative entrepreneurship) is a concept that brings to the fore the combination of several qualities, such as those of being an artist or a creator with that of being a businessman and, in so doing, proves the ability to add value to the economic development, especially where the traditional economy has failed. Creative businesses are considered to be those sectors of creation, which focus on technological development, generate profit and rethink culture as a catalyst for national and regional development, constantly adapting to the needs and requirements of their own clients and of competitive and dynamic markets [16]. Businesses in the creative industries begin their activity on a small scale [17], but show great diversity. For them, creativity was the core of the idea and maybe even the answer to the question: What should companies do to become more innovative, more creative in order to fulfil the dreams, passions and desires of customers? [18].

Entrepreneurship in the fashion design sector requires the entrepreneur to bring together the new design process and business practices [19]. Because the design process is often intuitive and experimental, and business development is generally approached systematically and logically, these two areas require new skills and new ways of thinking, their successful combination being certain to generate new challenges [20]. More and more, the textile industry and the fashion business is connected to what we call green marketing and green business. That means that the entrepreneurs are interested in how the market evolves, how the ecopreneurship develops, how the consumer behaviour is changing and how to deal with the new challenges for sustainability and competitiveness in long run [21-22]. It is proven that when accepted and assumed, business knowledge is a strong point and entrepreneurial designers can use creativity to start and grow their own business [23].

Studies in this field show that an exploratory approach can highlight creativity and innovation, in doing business especially at their beginning [24-25]. In our case, for fashion designers, these types of business vision offer an inspired solution to achieve competitive advantage in a dynamic and complex business world. And, it is to remark that this wind of change, of being more accountable and involved in transforming the organizations in sustainable ways, is felt in all fields of society, going from public administration to private sector and NGO's [26].

The strategy of sustainable development for clothing business is possible to be implemented by integrating the vertical value chain and paying attention to their major components as the creative department, fashion design, but also better marketing and sales approaches. At the same time the creativity and innovation must be understood as key elements for the architecture of the modern business in textile industry, but as well as in all types of activity.

\section{METHODOLOGICAL APPROACH}

In this paper, we aimed to connect creativity and business in that way so that it might give us the insight into the different aspects of creativity in the entrepreneurship for the domain of creative industries. The idea is to raise awareness of the importance of creativity for industry, to gain better understanding of the creativity process, as well as the concrete solutions of creativity and business integrations might be proposed. In order to do that, two main research goals are formulated:

- to see how designers perceive creativity, targeting the questions of (a) how they define creativity,

(b) identification of attribute of creative individuals, (c) identification of the factors that encourage creativity, (d) creativity process; 
- to consider how creativity helps entrepreneurs in business and how to perceive the link between those two.

In order to understand the complex meanings of creativity, we resorted to a qualitative approach, the data being gathered based on semi-structured interviews over a period of two calendar months. The interviews were conducted by a single researcher, always the same. Out of the 25 entrepreneur designers invited to participate in this research, only 17 responded to the invitation. Participation in the study was done on the basis of anonymity, which is why in the paper the designers are referred to using code names ranging from D1 to D17. Participation in the interviews was done on the principle of "convenience contacts" and, subsequently, using the snowball technique. The criteria for inclusion in the sample included being an entrepreneur from the western region of the country and belonging to a segment of the fashion industry. The geographical distribution targeted the major western cities as well as emerging cities.

Prior to the interviews, the participants were informed of the topic. The average time allocated to an interview was 45-60 minutes. The designers also completed a questionnaire with the help of which we collected a series of demographic data and significant experiences from their lives.

The transcribed interviews were processed using the qualitative analysis software ATLAS.ti. During the first stage, the data were coded for each category of questions in the interview, followed by a recording of the previous sections using codes that resulted from interviews inductively.

For a clearer presentation of the data, the topics discussed were illustrated in the paper with quotes from the interviews.

\section{EMPIRICAL RESULTS}

The transcribed interviews were processed using the qualitative analysis software ATLAS.ti. During the first stage, the data were coded for each category of questions in the interview, followed by a recording of the previous sections using codes that resulted from interviews inductively.

The interpretative analyses of the interviews led to the identification of 17 themes grouped into 4 categories: creativity in fashion design, attributes of creative individuals, the creative process and creativity in business.

As mentioned earlier, respondents were asked to talk about the evolution of their career in the fashion industry, with the interviews including questions regarding how entrepreneur designers define creativity, what the characteristics of creative individuals and the factors that encourage or inhibit creativity are and, business-wise, how creativity is helpful in their activity.

\section{Creativity in fashion design}

Regarding the evolution of their careers, the designers insisted that it was natural and incremental. We note the statements of two of the designers. In retrospect, D5 states about the beginning of his career: "I began modestly, by giving out what I was making. Upon realizing how great the demand was, I decided to put all the products up for sale, and now I only work on demand. I have been very pleased so far". In the same context, D6 gave the following account: "The evolution was organic. It started with the passion of a small child which then turned into a burning call. 10 years ago, I started to take on projects from customers, and 8 years ago I launched my first collection. But everything became orderly and settled five years ago when I started the company and the workshop".

The designers also proposed definitions for creativity, from their own perspective, with D6 and D11 describing the artistic and creative work as the passion of their life. The designers talked about the intrinsic motivation that caused them not to give up in difficult situations, in order to turn their ideas into reality. Thus, D6 mentions: "Creativity is the driving force of my life. I feel it start every day and always push me forward. Creativity is that aspect that helps me innovate, evolve and create a life of which I am proud", while D11 presents creativity through the lens of the different ways of exploring with what you have at hand: "A way of expressing your own style and ideas, uniqueness, innovation... there are certain attributes that some possess and others do not; in my case creativity starts from the materials I have available when I start working on something new. From a «fistful» of beads and crystals, I can make various products, I don't know ... a pair of earrings, a staple, a necklace - I choose the most successful option, on the spur of the moment. But for others it is just a «fistful» of beads and crystals..."

Also related to the definition of creativity was the subject of its origins, more precisely whether it is innate or not, and in this situation two types of answers stood out. The vast majority of respondents (14) correlated this question with the one linked to the definition of creativity and thus advanced the idea that individuals are born with talent that they subsequently develop through creativity, while 3 of the designers considered that anyone can develop their creative potential through learning and repetition.

With respect to the factors that stimulate/inhibit creativity, designers suggested there are numerous experiences that influence their creativity. Exposure to stimulating, challenging environments can increase creativity, as D1 states: "It is possible that a stroll or certain documentaries arouse my creativity... I do not force anything. Everything comes naturally".

Other designers, too, place the emphasis on nature as an incentive. However, the inhibitory factors seem to differ from one designer to another. More exactly: "Nature is always a helpful element. Even stress helps develop creativity. I have found that under stressful conditions, I show creativity. I often work better under pressure". D5 said, while D6 explained: "Natural light, rest and sun help a lot. And creativity is stifled by cold, darkness, stress, anxiety, or health 
factors". On the other hand, for D11, the inhibition of creativity is justified by the intense search: "While I work, I usually come up with the most ideas for future items (...) When I seek inspiration from other fields such as architecture, fashion, photography, etc. I'm completely confused, I can't stop searching and I can't focus on a subject, so too much research inhibits my creativity, I suppose".

The attributes of creative Individuals vs. the attributes of designers

One of the secondary aims of the research was to identify the opinions of the entrepreneur designers in the fashion industry regarding the attributes of creative individuals. The 17 designers constantly mentioned the same four attributes of creative people: imagination (14 designers), followed by originality (11 designers), passion for creation (9 designers) and intuition (8 designers) as can be seen in figure 1 .

Even when they talked about how they define creativity, some of the interview participants used qualities of creative people, mentioning passion almost as often as originality: D17 "For me, creativity means passion, harmony, sensitivity, emotion" or D13: "Freedom of expression, freedom to do what you like, how you like it and when you like it. Flexibility. Enthusiasm. It's actually... Passion".

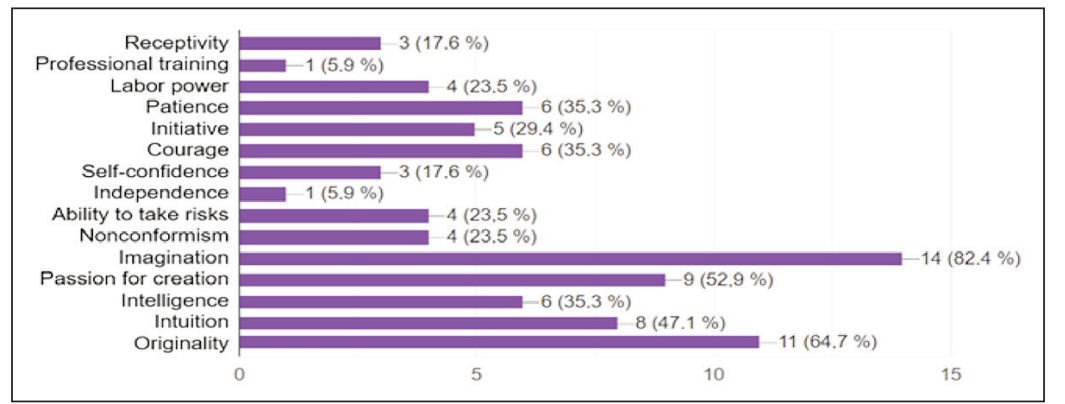

Fig. 1. The attributes of creative individuals
They all noted that the creative process is different from one product to another, from one creator to another, from one moment to another. For instance, D5 mentioned: "I start from the client's wish. He tells me what he wants from me, I ask him what colors and elements he generally wants to find in the final product and from there on everything comes only from my imagination".

It is worth noting that none of the designers has mentioned a perfect template for the creative process. Each of them spoke about diversity and at the same time about specificity. D1 emphasized: "I do not have a pattern of the creative process. It may start with a sketch that undergoes changes along the way, or I can sit at the work bench, simply start working and the ideas might spring to mind at any moment. Often an idea presents itself unexpectedly, so then I write it down, I look for solutions, do some trials, maybe sketch something and when I feel it may lead to something good, I start working".

\section{Creativity in business}

In the next decade, a quarter of all jobs will be completely new. The future is not predictable, but we will have to create it, and that means we will be forced to retrain our mind and adopt an entrepreneurial way of thinking. Companies, big or small, are challenged to adopt new business strategies, to create and develop a creative, innovative business environment. This is also evident from the opinions of the interviewed designers. D1: "There is a point where the two have to meet. A perfect balance must be created between them. Either you have someone to handle the business details, or you have to know when to put an end to the wave of creativity and pay attention to the

When asked which attributes define them as designers, their answers included most often the terms passion, patience and perseverance. Participants noted that being flexible is also a feature of creative people. Moreover, to the question "To what extent have these attributes impacted on your professional performance?" 10 of the designers responded "extensively", and the 7 others "a lot".

\section{The creative process}

The creative process seems to present a multitude of elements common to most interviewees, as D1, D5 and D6 explain. If, in the pre-interview stages, they considered creativity to be innate or developed, the vast majority consider inspiration as an incipient phase, as D6 does: "I start with inspiration, then I do research for that collection/that product. After the research, come the sketches and the materials. The next step is represented by the sketch and the design of the product itself. The trying on and the finish follow." reality and the material side". "You can be creative in any field [...]. Creativity is a business" mentions D11, while D13 looks at the results: "The business is the There is no art if it is not used, if no one sees it, it does not exist".

Also, D14 captures through his words the idea of success where creativity and business meet: "Innovation is always needed to succeed in business, it is very important to be creative, to always create new products that meet the needs of customers. For a company's financial success, creativity is essential". Each of the designers' opinions illustrates how they dispel the tensions and erase the boundaries between artistic creativity and business, as described by D8: "If art/design is based on subjectivity and emotion, then business is the objective and pragmatic part, and without both elements, a business in the creative industries would be pointless". purpose of the art, the way it reaches the consumer. 


\section{DISCUTIONS}

In order to elaborate this study, a number of 17 entrepreneur designers were asked to share their own opinions of creativity based on their own experiences, through semi-structured interviews. In the collected data set, descriptors were identified that refer to creativity, specific to each of the topics discussed. Following the data analysis, we were able to identify the most frequently used terms, revolving around the central ones ("creativity", "creative" and "business"), namely "work", "imagination", "product", "think", by taking into account the central position in the word cloud (figure 2). This actually reflects a very high density of these terms in the idiom of designers. The analysis of the network of keywords used by designers also revealed a particular focus on the following terms: "ideas", "passion" and "originality", especially when the discussions were about the attributes of creative people. When they referred to the creative process, designers quickly moved from "creativity" to "innovation", subsequently linking information about the materials used with terms such as "intuition", "patience" and finally, most of them talked about "results" and "creative solutions".

Based on the topics discussed regarding creativity, we proposed a model to help explain the opinions of the 17 entrepreneur designers from the fashion industry, a model that could contribute to the understanding of creativity in this sector (figure 3).

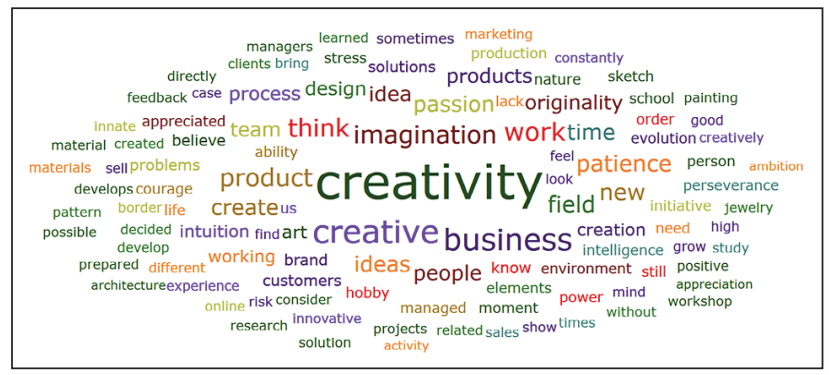

Fig. 2. Word cloud (Interviews processed using ATLAS.ti)
Based on the idea that designers regarded creativity as innate (being associated with the artist's actual activity) or developed (by making the distinction between talent and the ability to solve problems creatively), the creative process can be enriched by strategies meant to stimulate creativity, such as: participation in experience exchanges with other professionals, training/specialization courses and participation in conferences. Therefore, regardless of how they perceive the origin of creativity, and no matter how important it would be to use creativity stimuli (the designers' choices leaning entirely towards great and considerable importance), the participants in the study considered that these serve as a predisposition to the appearance of inspiration (D17: "Sometimes inspiration can be triggered by the sight of a colour, a pattern, or by the feeling of a texture or a fabric."). Whether doing research to advance, or making sketches to highlight the details or, rather, actually choosing the materials, one reaches the stage of making the pattern, a very important element in giving life to the idea. At this point, with the materials and the pattern ready, the cutting process may begin. A product can have several layers, it can be lined or made of different textures. For all these details, patterns must be made, based on which the cutting is done. The parts are then assembled and, before the finish, if the situation requires it, the sample is tried on and any necessary alterations are made so that the product conforms to the original idea. The last stage could be a final trying on or even the final touch.

\section{CONCLUSIONS}

The results show that although, initially, in their reports, designers regard creativity as a particularly important feature for those working in the fashion industry, when referring to the business, the notion of creativity actually appears to be associated with that of performance.

The analysis of the points of view of the entrepreneur designers who are active in the fashion industry

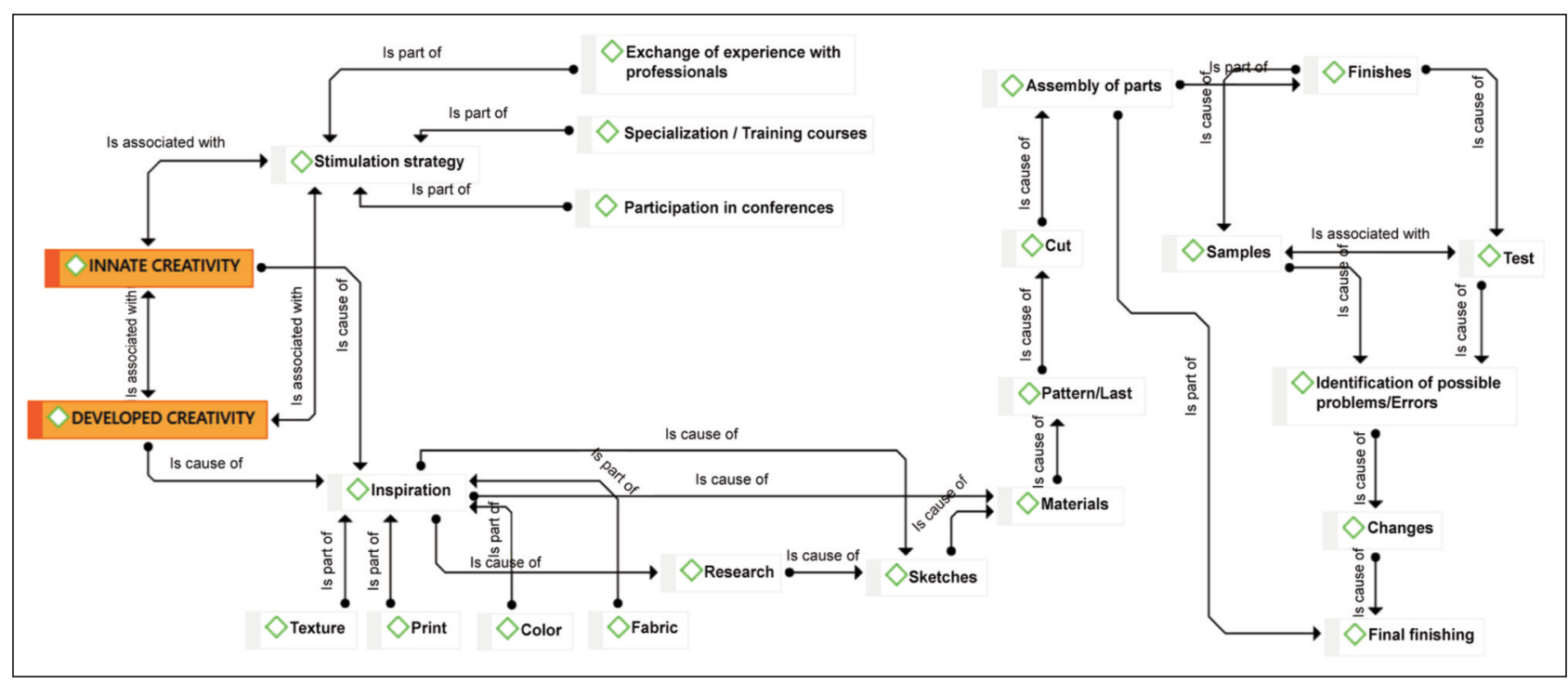

Fig. 3. The designers' perspectives on the creative process (processed using ATLAS.ti) 
shows that this pattern can be applied outside the creative industry. The origins of creativity, the attributes of creative people, the creative process and even the strategies to stimulate creativity can be transferred to any other field of activity, as they are not unique, and can thus contribute to a deeper understanding of the concept. Although the model has been validated by the research participants, they do not perceive it as the final outcome, but as a part/stage in the creative process. Since there are few studies conducted on the creativity of Romanian designers, our empirical study, through the obtained results, contributes to the literature by highlighting ways in which the entrepreneur designers manifest and develop their creativity in the context of the new business environment, in order to achieve sustainable competitive advantage.

This serves as proof that the business sector is one in which creativity can fit like a glove. Running a business is not an inhibiting factor for creativity. In fact, creativity can even be viewed as an art by anyone with an open mind, who is determined and willing to take risks while being able to identify opportunities and, in so doing, to bring out in an organized manner the latent potential of resources, so that in the end they can be used to create surplus value.

\section{LIMITS AND RECOMMENDATIONS}

We must keep in mind that this study is related to the designers' opinions of creativity in business and, as such, it provides a new perspective for future studies and additional approaches.

Regarding the answers analysed, it is necessary to pay attention to several limitations, out of which one of the main is the specific context: the fashion design industry in western Romania. Therefore, no generalization can be made regarding the entire creative sector. At the same time, the sample was partially self-selected, so our research could represent exclusively the opinion of those who were willing to participate in these interviews. The interviews largely involved the idea of introspection, and this can be considered difficult for those interviewed because they can omit certain relevant information. Although one of the limitations is the small number of interviewees, we chose a qualitative research to the detriment of a quantitative research because we sought a better understanding of the designers' ideas in certain situations, although this allows for the possibility of overestimating or underestimating them.

Future studies could support the present research if based on quantitative surveys mainly focused on the creativity of entrepreneur designers, and if the segmentation were targeted more precisely. Also, the features deemed irrelevant in the present paper might be revisited. Understanding creativity is necessary in the textile industry, and implicitly in fashion, as support for designers, because it can be the basis for improving education in the field: discovering a new idea by resorting to creativity is not enough to be successful, as creativity is a continuous process, just like education.

\section{ACKNOWLEDGEMENT}

This research was supported financially by the project CNFIS-FDI-2018-0582 - Supporting Excellence Research within The Bucharest University of Economic Studies in the context of the principles of sustainable development and open research. 6 . Supporting field research excellence in universities Beneficiary: The Bucharest University of Economic Studies.

\section{REFERENCES}

[1] Gomes, J., Rodrigues, F., Veloso, A., Creativity at Work: The Role of Context, In: Human Resource Management, Innovation and Performance, London, Palgrave Macmillan, 2015, 282-297

[2] Guilford, J., The nature of human intelligence, New York: McGraw-Hill, 1967

[3] Torrance, E., The Minnesota studies of creative behavior: National and international extensions, In: Journal of Creative Behavior, 1967, 1, 137-154

[4] Amabile, T., Creativity in context, New York: Westview, 1996

[5] Vincent, A.S., Decker B.P., Mumford, M. D., Divergent thinking, intelligence, and expertise: A test of alternative models, In: Creativity Research Journal, 2002, 14, 163-178

[6] Ford, C.M., Gioia, D.A., Guidelines for creative action taking in organizations, In: Creative action in organizations: Ivory tower visions and real world voices, Thousand Oaks, Sage, 1995, 355-366

[7] Zhou, J., George, G.J.M., Awakening employee creativity: The role of leader emotional intelligence, In: Leadership Quarterly, 2003, 14, 545-568

[8] Florida, R., The rise of the creative class and how it's transforming work, leisure, community, and everyday life, New York, NY: Basic Books, 2002

[9] Vernon, D., Hocking, I., Tyler, T., An evidence-based review of creative problem solving tools, a practitioner's resource, In: Human Resource Development Review, 2008, 15, 2, 230-259

[10] Esquivias, M., Creatividad: definiciones, antecedentes y aportaciones, In: Revista Digital Universitaria, 2004, 5, 1, $1-17$

[11] Santos, C.M., Uitdewilligen, S., Passos, A.M., Why is Your Team More Creative Than Mine? The Influence of Shared Mental Models on Intra-group Conflict, Team Creativity and Effectiveness, In: Creativity and Innovation Management, 2015, 24, 4, 645-658

[12] Agogue, M., Levillain, K., Hooge, S., Gamification of creativity: Exploring the usefulness of serious games for ideation, In: Creativity and Innovation Management, 2015, 24, 415-429

[13] Behrens, J., A lack of insight: An experimental analysis of R\&D managers decision making in innovation portfolio management, In: Creativity and Innovation Management, 2016, 25, 239-250 
[14] Ludvig, A., Tahvanainen, V., Dickson, A., Evard, C., Kurttila, M., Kosovic, M., Gerhard, W., The practice of entrepreneurship in the non-wood forest products sector: Support for innovation on private forest land, In: Forest Policy and Economics, 2016, 66, 31-37

[15] Tu, C., Yang, S., The role of entrepreneurial creativity in entrepreneurial processes, In: International Journal of Innovation, Management and Technology, 2013, 4, 2, 286-289

[16] Howkins, J., The Creative economy - How people make money from ideas, London: Penguin Books, 2001

[17] Kohn, K., Wewel, S., Skills, scope and success: an empirical look at the start-up process in creative industries in Germany, In: Creativity and Innovation Management, 2018, 27, 3, 295-319

[18] Khan, R., "Be creative" in Bangladesh? Mobility, empowerment and precarity in ethical fashion enterprise, In: Cultural Studies, 2019, 33, 6, 1029-1049

[19] Aakko, M., Niinimäki, K., Fashion Designers as Entrepreneurs: Challenges and Advantages of Micro-size Companies, In: Fashion Practice, 2018, 10, 3, 354-380

[20] Mills, C., Enterprise orientations: a framework for making sense of fashion sector start $\square$ up, In: International Journal of Entrepreneurial Behavior \& Research, 2011, 17, 3, 245-271

[21] Kardos, M, Gabor, M.R., Cristache, N., Green Marketing's Roles in Sustainability and Ecopreneurship. Case Study: Green Packaging's Impact on Romanian Young Consumers' Environmental Responsibility, In: Sustainability, 2019, 3/11, 873

[22] Epuran, G., Tescasiu, B., Todor, R.D., Sasu, K.A., Cristache, N., Responsible Consumption - Source of Competitive Advantages and Solution for Tourist Protection, In: Revista Amfiteatru Economic, 2017, 19, 45, 447-463

[23] Karra, N., The UK Designer Fashion Economy. Value Relationships - Identifying Barriers and Creating Opportunities for Business Growth. A Report Commissioned for NESTA, Center for Fashion Enterprise, London, 2008

[24] Gu, X., Developing entrepreneur networks in the creative industries - a case study of independent designer fashion in Manchester, In: Handbook of Research on Small Business and Entrepreneurship, Cheltenham UK, Edward Elgar Publishing, 2014, 358-373

[25] Vaghely, I.P., Julien, P., Are opportunities recognized or constructed?, In: Journal of Business Venturing, 2010, 25, 1, 73-86

[26] Eliya, Y., Bibu, N., The Relation between Accountability and the Climate of Service in Israeli Public organisations, In: Revista de Management Comparat International/Review of International Comparative Management, 2019, 20, $1,30-51$

Authors:

$$
\begin{aligned}
& \text { DENISA BOGDANA ABRUDAN }{ }^{1} \text {, MĂDĂLINA DUMITRIȚA MATICIUC }{ }^{1} \text {, } \\
& \text { MARIAN NĂSTASE }{ }^{2} \text {, MARGARETA STELA FLORESCU², DANA CODRUȚA DĂIANU }{ }^{3}
\end{aligned}
$$

${ }^{1}$ West University of Timisoara, Faculty of Economics and Business Administration, Management Department, J.H. Pestalozzi Street, no.16, 300115, Timisoara, Romania e-mail: denisa.abrudan@e-uvt.ro, madalina.maticiuc@e-uvt.ro

${ }^{2}$ Bucharest University of Economic Studies, Faculty of Management, Management,

Piata Romana, no. 6, 010374, Bucharest, Romania

e-mail: margareta.florescu@ari.ase.ro

${ }^{3}$ Aurel Vlaicu University of Arad, Faculty of Economics, Economics Department, B-dul Revolutiei, no. 77, 310130, Arad, Romania

e-mail: cddaianu@yahoo.com

Corresponding author:

MARIAN NĂSTASE

e-mail: nastasem1@yahoo.com 